\title{
Buccal caffeine for the routine reversal of Persantine
}

\section{To the Editor,}

Lack of a reliable supply of intravenous Aminophylline for reversal of Persantine following pharmacologic MPI necessitated a search for an alternative.

Caffeine, Theophylline, and Aminophylline are all Xanthine derivatives, acting as nonselective adenosine receptor antagonists thereby inhibiting Adenosine. ${ }^{1}$ Caffeine is structurally similar to Theophylline, (Caffeine $=$ $\mathrm{C}_{8} \mathrm{H}_{10} \mathrm{~N}_{4} \mathrm{O}_{2}$, Theophylline $=\mathrm{C}_{7} \mathrm{H}_{8} \mathrm{~N}_{4} \mathrm{O}_{2}$ ).

Buccal caffeine $40 \mathrm{mg}$ is available as an over the counter preparation called Synergy ${ }^{\mathrm{TM}}$. $^{2}$ The controversy about Caffeine's efficacy relates to delayed absorption and effective blood levels. ${ }^{3}$ We report our experience with buccal Caffeine.

Nine hundred and fifty-four consecutive patients undergoing Persantine MPI were studied. Patients gave signed informed consent. Two minutes after the Sestamibi dose Synergy ${ }^{\mathrm{TM}}$ containing $40 \mathrm{mg}$ of Caffeine was administered via the buccal route.

There were 534 males and 420 females (mean age of $66.8 \pm 10.9$ years). Fifty-five symptomatic patients, with ischemic ECG changes and/or hypotension required Aminophylline (5.8\%). One hundred and seven symptomatic patients with ischemic ECG changes and/ or hypotension did not require Aminophylline (11.2\%). Sixty-nine asymptomatic patients with ischemic ECG changes and/or hypotension did not require Aminophylline (7.2\%). Using these figures, a very selective utilization of Aminophylline could have been a reduced from $24.2 \%$ to $5.8 \%$. Our use of Aminophylline was reduced from routine (100\%) to $5.8 \%$.
Buccal Caffeine $40 \mathrm{mg}$ is an alternative method of reversing Persantine. Intravenous Aminophylline must be available for those patients who fail to respond. Any other Caffeine preparation (coffee, tea, chocolate, energy drinks, and caffeine tablets) would have delayed absorption and therefore less likely to be effective. Lexiscan (Regadenoson) is only available through a "special access" program in Canada. Buccal Caffeine should also reverse the adverse effects of Lexiscan.

We use buccal Caffeine routinely after Persantine MPI and reserve intravenous Aminophylline for the caffeine non-responders. We are currently investigating an $80 \mathrm{mg}$ dose of buccal Caffeine to see if we can further reduce the percentage of non-responders.

Murray Matangi, MB ChB, FRACP, FRCPC, FACP, FACC Peter Dutchak, MD, FRCPC

Kingston Heart Clinic, Kingston, ON, Canada murraymatangi@hotmail.com

\section{References}

1. Baraldi PG, Tabrizi MA, Gessi S, Borea PA. Adenosine receptor antagonists: Translating medicinal chemistry and pharmacology into clinical utility. Chem Rev 2002;108:238-63.

2. www.synergystrips.com. Accessed 18 June 2014.

3. Salcedo J, Kern MJ. Effects of Caffeine and Theophylline on coronary hyperemia induced by adenosine or dipyridamole. Catheter Cardiovasc Interv 2009;74:598-605.

doi:10.1007/s12350-014-9926-0 